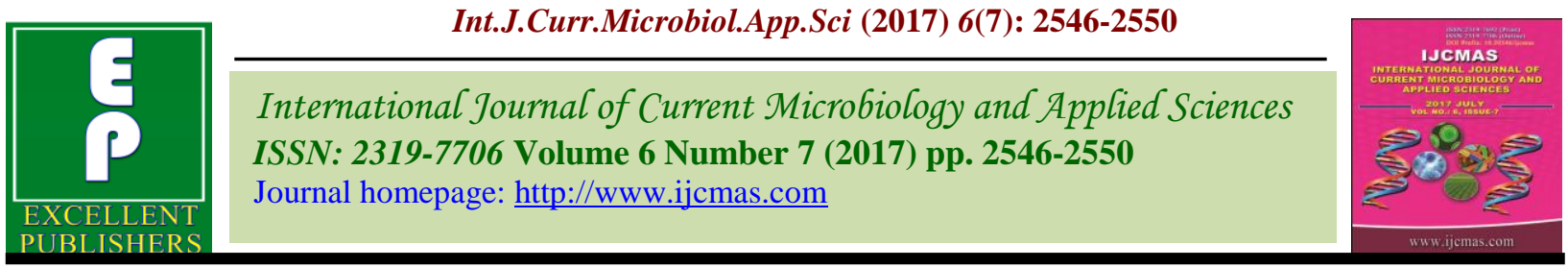

Original Research Article

https://doi.org/10.20546/ijcmas.2017.607.300

\title{
Performance of Bush Pepper under New Alluvial Zone of West Bengal, India
}

\author{
Sarthak Bhattacharya* and Apurba Bandyopadhyay
}

\begin{abstract}
Department of Spices and Plantation Crops, Bidhan Chandra Krishi Viswavidyalaya, Mohanpur, Nadia, West Bengal, India

*Corresponding author
\end{abstract}

\begin{tabular}{|c|c|}
\hline & A B S T R A C T \\
\hline & $\begin{array}{l}\text { India has been considered as the "Spice Bowl of the World". Black pepper (Piper nigrum } \\
\text { L.), is a perennial export oriented cash crop of India. It is also known as "King of Spices". } \\
\text { The demand for black pepper and its products is increasing year by year in the world } \\
\text { market but the production is not up to the level. At present the productivity in India is very }\end{array}$ \\
\hline $\begin{array}{l}\text { Key w o r d s } \\
\text { Bush Pepper, } \\
\text { Growth, Yield. }\end{array}$ & $\begin{array}{l}\text { low due to non-adoption of good agricultural practices (Thangaselvabal et al., 2008). In } \\
2016-17 \text { (Est.), India produces } 55500 \text { tons of Black pepper from } 131230 \text { ha area with a } \\
\text { productivity of } 2.36 t / \text { ha (Spices Board India, 2016-17). The present investigation on } \\
\text { performances of different varieties of black pepper as bush pepper has been carried out } \\
\text { from September } 2013 \text { to April } 2014 \text { at GeneBank. BCKV. Kalvani. Nadia. West Bengal. }\end{array}$ \\
\hline Article Info & Three varieties of black pepper like Panniyur-2, Panniyur-4 and Panniyur-5 were \\
\hline $\begin{array}{l}\text { Accepted: } \\
\text { 23 June } 2017 \\
\text { Available Online: } \\
\text { 10 July } 2017\end{array}$ & $\begin{array}{l}\text { considered as treatment. Different growth and yield parameters were evaluated. Very } \\
\text { meager information is available on performance of Bush Pepper variety under New } \\
\text { Alluvial zone. Considering the growth and yield parameters of bush pepper under West } \\
\text { Bengal condition, it may be concluded that the performance of Panniyur- } 5 \text { is superior with } \\
\text { respect to all the growth parameters particularly intermodal length }(9.02 \mathrm{~cm}) \text {, bush length }\end{array}$ \\
\hline & $\begin{array}{l}(103.52 \mathrm{~cm}) \text {, number of branches/bush }(63.8) \text { during the period of observation as well as } \\
\text { during the initial years off lowering and yield attributing parameters Panniyur-5 recorded } \\
17 \text { no. of spike/bush with spike wt. of } 21 \mathrm{~g} \text { and spike yield of } 357 \mathrm{~g} / \mathrm{bush} \text { as compared to } \\
\text { Panniyur-2. }\end{array}$ \\
\hline
\end{tabular}

\section{Introduction}

Black pepper (Piper nigrum L.), of the family Piperaceae, is a perennial export oriented spice crop in India. It is gaining popularity world-wide as an indispensable food adjunct due to its unique pungency and associated flavour. It is regarded as "King of Spices" and "Black Gold" (Parthasarathy et al., 2008) and having great socio-economic importance. The crop has great economic importance in some other countries viz. Thailand, Indonesia, Malaysia and Brazil. The productivity of black pepper in India is being challenged by countries like Malaysia and it is ascribed basically to improper management practices (Hamza and Sadanandan, 2005). It is the largest foreign exchange earner among spices and the average quantity exported from India accounts for more than $70 \%$ of the total production. At present the productivity in India is very low due to the non-adoption of good agricultural practices (Thangaselvabal et al., 2008). Many researchers have reported on the need of integrated plant nutrition management for soil fertility and crop production (Ayeni, 2011; Singh et al., 2011; Aticho et al., 2011; Parthasarathy et al., 2010; 
Peter et al., 2000) documented that less fertiliser use, low fertiliser use efficiency and micro nutrient deficiency are the major reasons for the low productivity of all spices grown in India including black pepper. Pepper is the world's most important and valued spices. It is used as an important component of many recipes and to flavour foods. From the berries of Piper nigrum L. several condiments are produced like black pepper, white pepper, green pepper etc. Other important commercial products derived from the pepper plant are pepper oil, cookies \& crackers, pepper tea, perfumes, sausage preservation etc. In 2016-17 (Est.), India produces 55500 tons of Black pepper from 131230 ha area with a productivity of 2.36t/ha. (Spices Board India, 2016-17) Indian Institute of Spices Research (IISR), Calicut has come out with a new technology which can relish the culinary needs for pepper-throughout the year. Black pepper vines are usually cultivated by allowing them to climb on either living (on trees) or nonliving ( $\mathrm{RCC}$ posts, granite pillars, teak poles etc.) supports. Black pepper vines while climbing on these supports put forth fruiting branches called laterals which produce flowers and fruits. The normal way of producing planting material of black pepper is to use rooted cuttings (single or 3 nodded) of runner shoots or climbing shoots. This ensures that the plant turn into vine after climbing on a support and produce fruiting branches (Plagiotropes) all around the support. But when the laterals are used as planting material, the resultant plants grow like a "Bush". These plants produce numerous laterals throughout the year, unlike vines.

One-year-old healthy fruiting branches are selected with 3 to 5 nodes and all the leaves except the flag leaf are removed and planted in a shade area in the nursery, either in trenches or in polybags $(45 \times 30 \mathrm{~cm})$ containing moist coir dust. Before planting, the cuttings are dipped in $1000 \mathrm{ppm}$ of IBA for 45 seconds. After planting, the trenches are covered with polythene sheets and in the case of polybags, the mouth is tightly tied with coir thread to avoid moisture loss. They normally root in 30 to 50 days. Such rooted cuttings are planted in pots or fields after sufficient hardening treatment. Cuttings grow like a bush and flower in the same year itself.

\section{Materials and Methods}

The present investigation on performances of different varieties of black pepper as bush pepper has been carried out from September 2013 to April 2014 at GeneBank, BCKV, Kalyani, Nadia, West Bengal. The research station is located at $22.97^{\circ}$ North latitude, $88.43^{\circ}$ East longitude having an average

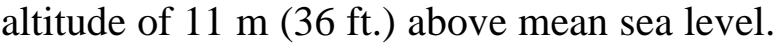
The soil of the experimental field was Gangetic alluvial.

Three varieties of black pepperlikePanniyur2, Panniyur-4 and Panniyur-5were observed during the period of time. The growth parameters such as bush height $(\mathrm{cm})$, intermodal length $(\mathrm{cm})$, leaf stalk length $(\mathrm{cm})$, leaf area index (L.A.I.), number of branches/ bush and branch diameter ( $\mathrm{mm})$ were recorded and yield attributing parameters viz. Number of spikes/bush, Spike weight (g),Spike yield/bush (g), Spike length (cm), Stalk length of spike $(\mathrm{cm})$, and number of berries/spike were recorded.

\section{Results and Discussion}

\section{Crop growth parameters of different Bush Pepper varieties}

\section{Bush height}

It is revealed from table 1 that with respect to bush height, Panniyur-2 recorded maximum increase in height i.e. $34.6 \mathrm{~cm}$ with attainment 
of $107.2 \mathrm{~cm}$ at final stage of observation followed by Panniyur-4 where increase in bush height was recorded $31.3 \mathrm{~cm}$ with maximum bush height of $92.9 \mathrm{~cm}$. In Panniyur-5 increase in bush height was recorded least with $20.9 \mathrm{~cm}$.

\section{Intermodal length}

With respect to intermodal length of different varieties of bush pepper, it was recorded that maximum $(2.2 \mathrm{~cm})$ increase in intermodal length was recorded in Panniyur-2 variety followed by Panniyur-5, where increase in intermodal length was $1.8 \mathrm{~cm}$. lowest increases in intermodal length was recorded in Panniyur-4, i.e. $1.6 \mathrm{~cm}$.

\section{Number of branches}

Data presented in table 2 recorded that maximum number of branches was observed in Panniyur-5 bushes (63.8) followed by Panniyur-2 bushes (35) and lowest number of branches was recorded in Panniyur-4 (28.8). The increase in number of branches within the period of observation was maximum in Panniyur-5 bushes (28.8) followed by Panniyur-2 (14) and Panniyur-4 bushes (11.8) as compared to the initial observation recorded on number of branches. Primary branch number was recorded maximum (7) in Panniyur-2, followed by Panniyur-5 (3.6) and Panniyur-4 (1.8).Secondary branch number was recorded maximum (28) in Panniyur-5 followed by Panniyur-2 (18) and Panniyur-4 (7.4).

Tertiary branch number was recorded maximum in Panniyur-5 (32.2) followed by Panniyur-4 (19.6) and Panniyur-2 (10).Regarding diameter of primary branches maximum diameter was recorded in Panniyur2 (19mm) followed by Panniyur-5 (18.55mm) and Panniyur-4 (17.08mm).

Diameter of secondary branch was recorded maximum in Panniyur-5 $(8.04 \mathrm{~mm})$ followed by Panniyur-4 $(7.97 \mathrm{~mm})$ and Panniyur-2 (7.21 mm).Diameter of tertiary branch was recorded maximum in Panniyur-2 (4.68mm) followed by Panniyur-4 $(4.60 \mathrm{~mm})$ and Panniyur-5 (4.16mm).

Among the 3 different type of branches; primary, secondary and tertiary; primary branch recorded maximum diameter in all the variety, followed by secondary branches and least diameter was recorded in tertiary branches.

Table.1 Growth parameter studies in different varieties of bush pepper

\begin{tabular}{|c|c|c|c|c|c|c|}
\hline \multirow[t]{2}{*}{ Date } & \multicolumn{2}{|c|}{ Panniyur-2 } & \multicolumn{2}{|c|}{ Panniyur-4 } & \multicolumn{2}{|c|}{ Panniyur-5 } \\
\hline & $\begin{array}{c}\text { Bush } \\
\text { Height(cm) }\end{array}$ & $\begin{array}{l}\text { Internodal } \\
\text { Length }(\mathrm{cm})\end{array}$ & $\begin{array}{c}\text { Bush } \\
\text { Height } \\
\text { (cm) }\end{array}$ & $\begin{array}{l}\text { Internodal } \\
\text { Length }(\mathrm{cm})\end{array}$ & $\begin{array}{c}\text { Bush } \\
\text { Height } \\
\text { (cm) }\end{array}$ & $\begin{array}{l}\text { Internodal } \\
\text { Length }(\mathrm{cm})\end{array}$ \\
\hline 25.09 .13 & 72.6 & 6.02 & 61.6 & 5.2 & 82.6 & 7.2 \\
\hline 22.10 .13 & 79.2 & 6.24 & 65.7 & 5.4 & 84.14 & 7.3 \\
\hline 24.11 .13 & 83.84 & 6.64 & 70.28 & 5.64 & 87.24 & 7.7 \\
\hline 26.12.13 & 89.36 & 7.24 & 77.7 & 6.0 & 90.94 & 8.08 \\
\hline 27.01 .14 & 91.8 & 7.32 & 79.36 & 6.06 & 92.62 & 8.12 \\
\hline 27.02.14 & 100.3 & 7.76 & 86.44 & 6.4 & 97.56 & 8.6 \\
\hline 25.03 .14 & 104.6 & 7.96 & 89.8 & 6.6 & 100.62 & 8.84 \\
\hline 26.04 .14 & 107.2 & 8.2 & 92.94 & 6.78 & 103.52 & 9.02 \\
\hline
\end{tabular}


Table.2 Studies on number of branches, branch diameter and L.A.I. of different varieties of bush pepper

\begin{tabular}{|c|c|c|c|c|c|c|c|c|c|}
\hline \multirow[t]{2}{*}{ VAR. } & \multicolumn{2}{|c|}{$\begin{array}{c}\text { NO.OF } \\
\text { BRANCHES }\end{array}$} & \multicolumn{2}{|c|}{ PRIMARY } & \multicolumn{2}{|c|}{ SECONDARY } & \multicolumn{2}{|c|}{ TERTIARY } & \multirow[t]{2}{*}{$\begin{array}{c}\text { L.A.I. } \\
\text { (sq. cm) }\end{array}$} \\
\hline & INITIAL & FINAL & NO & $\begin{array}{l}\text { DIAMETER } \\
(\mathbf{m m})\end{array}$ & NO & $\begin{array}{l}\text { DIAMETER } \\
(\mathrm{mm})\end{array}$ & NO & $\begin{array}{l}\text { DIAMETER } \\
(\mathbf{m m})\end{array}$ & \\
\hline P-2 & 21.4 & 35 & 7 & 19 & 18 & 7.21 & 10 & 4.68 & 46.4 \\
\hline P-4 & 17 & 28.8 & 1.8 & 17.08 & 7.4 & 7.97 & 19.6 & 4.60 & 52.39 \\
\hline $\mathbf{P - 5}$ & 38 & 63.8 & 3.6 & 18.55 & 28 & 8.04 & 32.2 & 4.16 & 38.07 \\
\hline
\end{tabular}

Table.3 Studies on yield attributing parameters of different varieties of bush pepper

\begin{tabular}{|l|l|l|l|l|l|l|}
\hline VARIETY & $\begin{array}{l}\text { NO. OF } \\
\text { SPIKES/ } \\
\text { BUSH }\end{array}$ & $\begin{array}{l}\text { SPIKE } \\
\text { WT }(\mathrm{g})\end{array}$ & $\begin{array}{l}\text { SPIKE } \\
\text { YIELD } \\
(\mathrm{g}) / \mathrm{bush}\end{array}$ & $\begin{array}{l}\text { SPIKE } \\
\text { LENGTH } \\
(\mathrm{cm})\end{array}$ & $\begin{array}{l}\text { STALK } \\
\text { LENGTH OF } \\
\text { SPIKE }(\mathrm{cm})\end{array}$ & $\begin{array}{l}\text { NO.OF } \\
\text { BERRY/SPIKE }\end{array}$ \\
\hline P-2 & $\mathbf{8}$ & $\mathbf{1 5}$ & $\mathbf{1 2 0}$ & $\mathbf{9 . 9 8}$ & $\mathbf{2 . 2 3}$ & 21.47 \\
\hline P-4 & $\mathbf{0}$ & -- & -- & $\begin{array}{l}\text { No } \\
\text { flowering }\end{array}$ & No flowering & No flowering \\
\hline P-5 & 17 & 21 & 357 & 14.41 & 2.86 & 32.67 \\
\hline
\end{tabular}

Crop yield parameters of different bush pepper varieties

Data presented in table 3 revealed that wide variation of different yield attributing parameters existed among different varieties of bush pepper. Out of the 3 varieties, Panniyur-4 did not come to flowering after 3 years of planting. Out of the other 2 varieties maximum number of spike (17) was recorded in Panniyur-5 followed by Panniyur-2 (8). Maximum number of spike/bush, spike wt. (21g), spike yield (357g), spike length $(14.41 \mathrm{~cm})$, stalk length of spike $(2.86 \mathrm{~cm})$, number of berries/spike (32.67) was recorded in Panniyur-5 as compare to Panniyur-2 in the respective parameters.

Evaluation of three varieties of bush pepper under the Gangetic alluvial plains of WB indicated that there was wide variation among the variety with respect to their growth and yield parameters. Panniyur-5 showed superior performance with respect to increment in intermodal length $(9.02 \mathrm{~cm})$, bush length $(103.52 \mathrm{~cm})$, total number of branches $(63.8)$ and primary (3.6), secondary (28) and tertiary (32.2) branches as compare to Panniyur-2 and Panniyur-4 varieties. With respect to yield attributing parameters Panniyur-5 recorded superior performance with respect to Number of spikes/bush (17), spike weight (21g), spike yield/bush $(357 \mathrm{~g})$, spike length $(14.41 \mathrm{~cm})$, Number of berries/spike (32.67), as compare to Panniyur-2 variety. Arya et al., (2003), Amma et al., (2002), Nayer et al., (2002) also recorded wide variation among the cultivars of black pepper under various agro climatic conditions.

\section{References}

Amma, S.P., Nybe, E.V., Sujatha, V.S. and Prabhakaran, P.V. (2001). Survey, evaluation and identification of black pepper cultivars. J. Trop. Agri. 39(1): 912

Parthasarathy, V.A., Chempakam, B. and 
Zachariah, T.J. (2008). Black Pepper. In: Chemistry of spices. CAB International, USA, pp.21-40

Hamza, S. and Sadanandan, A.K. (2005). Effect of source and method of application of zinc on yield and quality of black pepper (Pipernigrum L.).J.SpicesAromat.Crops. 14 (2): 117 121

Ayeni, L.S. (2011). Integrated plant nutrition management. A panacea for sustainable crop production in Nigeria.Int.J.Soilsci.6: 19-24

Aticho, A., Elias, E., and Diels, J. (2011). Comparative analysis of soil nutrient balance at farm level. A case study in Jimmazone, Ethiopia.Int.J.Soilsci.6: 259-266

Peter, K.V., Srinivasan, V., and Hamza, S.
(2000). Nutrient management in spices. Fertilizer news.45: 13-28

Arya, K., Rajagopalan, A., Satheesan, K.N., Nair P.K.U., Mammotty, K.P., Zacharia, G. and Vanaja, T. (2003). Panniyur-6 and Panniyur-7-high yielding black pepper selections for Kerala. Indian J. Genetics Pl.Breeding.63 (4): 363-64

Nair, P.K.U., Vanaja, T., Neema, V.P., Arya, K. and Sivakumar, G. (2002).Panniyur 6-a newly released high yielding variety of black pepper. Indian J. Arecanut, Spicesand Medicinal Plants.4 (2): 81

Thangaselvabal, T., Justin, C.G.L. and Leelamathi, M. (2008). Black pepper (Piper nigrum L.) 'The king of spices'-a review.Agri.Rev.29 (2): http://www.indianspices.com

\section{How to cite this article:}

Sarthak Bhattacharya and Apurba Bandyopadhyay. 2017. Performance of Bush Pepper under New Alluvial Zone of West Bengal. Int.J.Curr.Microbiol.App.Sci. 6(7): 2546-2550. doi: https://doi.org/10.20546/ijcmas.2017.607.300 